\title{
The Philosophical Case for Open Theism
}

\author{
Alan Rhoda \\ Received: 31 May 2007 / Accepted: 11 June 2007 / \\ Published online: 21 August 2007 \\ (C) Springer Science + Business Media B.V. 2007
}

\begin{abstract}
The goal of this paper is to defend open theism vis-à-vis its main competitors within the family of broadly classical theisms, namely, theological determinism and the various forms of non-open free-will theism, such as Molinism and Ockhamism. After isolating two core theses over which open theists and their opponents differ, I argue for the open theist position on both points. Specifically, I argue against theological determinists that there are future contingents. And I argue against non-open free-will theists that future contingency is incompatible with the future's being epistemically settled for God. This paper is a follow-up to the author's Rhoda (Religious Studies, 2008) which was delivered during the APA Pacific 2007 Mini-Conference on Models of God.
\end{abstract}

Keywords Open theism · Free-will theism · Theological determinism · Arthur Prior

Given all the forms of theism out there, why be an 'open theist'? Indeed, why be a theist of any sort? These are both good questions but too broad to be manageable in a paper of this size. To make my job easier I'm going to assume that some version of theism is correct. Even more restrictively, I'm going to assume that some version of broadly classical theism is correct. By 'broadly classical theism' (hereafter 'theism') I mean the view that God is a personal being who exists necessarily, ${ }^{1}$ who possesses a maximal set of compossible great-making properties, including maximal power, knowledge, and goodness, and who created the world ex nihilo ${ }^{2}$ and can unilaterally intervene in it as he pleases. ${ }^{3}$ Within these constraints, I want to argue for open

\footnotetext{
${ }^{1}$ The precise nature of God's necessity is a matter of some debate among theists. Some think that God is necessary in the broadly logical sense of existing in all possible worlds. Others think that God is 'metaphysically' necessary in the sense of existing in all non-empty possible worlds, such that if anything exists, then God does too. It is not necessary for my purposes to take a stand on this debate, so I'll simply take 'God exists necessarily' to mean that God is at least metaphysically necessary.

${ }^{2}$ By creation ex nihilo I simply mean that God did not fashion creation out of any preexisting matter or stuff á la Plato's Demiurge.

${ }^{3}$ The last clause is meant to exclude process theism. Open theists have generally been quite explicit that they mean to stay within the broadly classical theistic tradition. See esp. Cobb and Pinnock (2000).
}

A. Rhoda $(\bowtie)$

Department of Philosophy, University of Nevada Las Vegas, Las Vegas, NV 89154, USA

e-mail: alan.rhoda@unlv.edu 
theism over against its two chief competitors, which I'll call 'theological determinism' and 'non-open free-will theism', respectively.

Here's the outline. I begin by giving a precise definition of 'open theism' in terms of which I then define both 'theological determinism' and 'non-open freewill theism'. As I will expound in more detail shortly, open theism has three core commitments - theism, future contingency, and what I call 'EC incompatibility'. Theological determinists are distinguished by their rejection of future contingency, and non-open free-will theists by their rejection of EC incompatibility. In the next two sections I argue for both of those contested theses. The result, I hope, is a cogent philosophical argument that open theism is the only viable form of theism, in the broadly classical sense of that term.

\section{Open Theism and Its Competitors}

As I've argued in detail elsewhere, ${ }^{4}$ open theism may be defined as a commitment to the following propositions:

(1) Theism: God is a personal being who exists necessarily, who possesses a maximal set of compossible great-making properties, including maximal power, knowledge, and goodness, and who created the world ex nihilo and can unilaterally intervene in it as he pleases.

(2) Future contingency: There are future contingents. In other words, the future is, as of now and in some respects, causally open. ${ }^{5}$

(3) EC incompatibility: It is impossible that the future be epistemically settled ${ }^{6}$ for someone in any respect in which it is causally open.

(4) Epistemic openness of the future for God: The future is, as of now and in some respects, epistemically open for God.

This list can actually be shortened since (4) is a logical consequence of (1), (2), and (3). ${ }^{7}$ It's helpful, however, to make (4) explicit, since that has been a focal point of controversy in discussions of open theism. Indeed, a central dialectic among theists consists in whether to accept both (2) and (3), and consequently (4), or whether to reject (4) and with it either (2) or (3). In these terms, open theism falls squarely between two competing theistic traditions: the 'theological determinism' of

\footnotetext{
${ }^{4}$ Rhoda (2008).

${ }^{5}$ The future is 'causally open' with respect to state of affairs X, present time $t$, and future time $t^{*}$ if and only if, given all that exists as of $t$, it is really possible both that $\mathrm{X}$ obtains at $t^{*}$ and that $\mathrm{X}$ does not obtain at $t^{*}$. In other words, whether $\mathrm{X}$ obtains at $t^{*}$ or not is, as of $t$, a future contingent.

${ }^{6}$ The future is 'epistemically open' for person $\mathrm{S}$ at time $t$ with respect to some conceivable future state of affairs $\mathrm{X}$ if and only if for some future time $t^{*}$ neither "X will obtain at $t^{*}$ " nor "X will not obtain at $t^{*}$ " is infallibly known by $\mathrm{S}$ at $t$. The future is 'epistemically settled' for $\mathrm{S}$ at $t$ in all and only those respects in which it is not epistemically open for $\mathrm{S}$ at $t$.

${ }^{7}$ By (1) God exists and has maximal possible knowledge. Hence, the future must be epistemically settled for God if such knowledge is possible for him to have. By (2) and (3), however, there is knowledge that God cannot have, namely, he cannot know of a future contingent event that it 'will' happen or that it 'will not' happen.
}

글 Springer 
the late Augustine, Luther, Calvin, and Edwards, on the one hand; and the "non-open free-will theism, ${ }^{8}$ of Ockham, Molina, and Arminius, on the other. Both of these traditions reject (4) and so, to preserve consistency, give up at least one of the other commitments. Theological determinists reject (2) while typically accepting (3). In contrast, non-open free-will theists unanimously accept (2) and consequently reject (3). Thus, open theists side with non-open free-will theists over against theological determinists by affirming future contingency. And they side with (most) theological determinists over against other free-will theists by affirming EC incompatibility.

Now that we understand what open theism is and how it contrasts with both theological determinism and non-open free-will theism, I want to set forth my argument for open theism. Taking (1) for granted, my case has two stages. First, I give several reasons for accepting (2), and therefore for rejecting theological determinism. Second, I argue indirectly for (3) based on semantic considerations. Thus, instead of arguing directly for (3), as others have done, ${ }^{9}$ I'm going to argue instead for a related principle:

(5) AC incompatibility: It is impossible that the future be alethically settled ${ }^{10}$ in any respect in which it is causally open.

Proposition (3) follows quickly from (5) given the platitude that what is not true cannot be known. Hence, a cogent argument for (5) is also a cogent argument for (3). I have two reasons for focusing on (5). First, the debate over (3) is well-worn by now and covers a host of complex issues, from the 'hard fact' / 'soft fact' distinction, to the status of 'power entailment principles' and of so-called 'counterfactuals of creaturely freedom'. ${ }^{11}$ By focusing on (5) I avoid miring myself in those muddy waters and shift the discussion into largely unexplored territory. Second, the most plausible versions of open theism affirm both (3) and (5), and so (5) ought to be defended anyway. After all, if we suppose that (3) can be true while (5) is false, then future contingency is compatible with the future's being both epistemically open for God and alethically settled. This allows what is true and what is knowable-for-God to come apart. As a result, open theists who reject (5) have to deny that God is essentially omniscient in the traditional sense of knowing all and only truths. ${ }^{12}$ One problem with this is that it's not at all clear that truth and knowability-for-God could come apart. As creator and sustainer of everything apart from himself, how could

\footnotetext{
${ }^{8}$ The term 'free-will theism' refers to the family of views defined by commitment to (1) broadly classical theism and (2) future contingency, with the latter understood to entail creaturely libertarian freedom. See Basinger (1996). Since open theists generally accept that some creatures have libertarian freedom, they qualify as free-will theists. 'Non-open free-will theists' are distinguished from open theists by their rejection of (3) and (4).

${ }^{9}$ Especially notable in this regard is Hasker (1989).

${ }^{10}$ The future is 'alethically open' at time $t$ with respect to some conceivable future state of affairs $\mathrm{X}$ if and only if for some future time $t^{*}$ neither "X will obtain at $t^{*}$ " nor "X will not obtain at $t^{*}$ " is true at $t$. The future is 'alethically settled' at $t$ with respect to $\mathrm{X}$ just in case it is not alethically open at $t$ with respect to $\mathrm{X}$.

${ }^{11}$ On these and other related issues, see Fischer (1989) and Zagzebski (1991).

${ }^{12}$ See Hasker (1989), 187; Hasker (2001), 110-111.
} 
God fail to have exhaustive knowledge of reality? And if God does have exhaustive knowledge of reality, then how could he fail to know all truths given that truth supervenes on being? In the absence of compelling responses to those questions, open theists who accept (3) and deny (5) invite the charge that they 'diminish' God by denying his essential omniscience. ${ }^{13}$ In contrast, open theists who accept (5) can accept God's essential omniscience without qualification, and they can offer (5) as a clear rationale for the truth of (3).

\section{On Behalf of Future Contingents}

There are several positive reasons for believing that the future contingency thesis, (2), is correct. First, it receives support from the fact that when we engage in deliberation, we invariably conceive of our choice situation as one in which we have it in our power to make one of several mutually exclusive choices. At the time, each possibility seems open, unnecessitated, a future contingent. There are of course wellknown strategies for explaining away such 'seemings' as mere appearances. The mere fact that our options seem to be open to us is not a proof that they really are. Nevertheless, the experience of deliberation is prima facie evidence of future contingency. All other things being equal, the fact that the disbeliever in future contingents has to explain away the appearances, whereas the believer in future contingency can accept them at face value leaves the latter in the stronger dialectical position.

Second, the case for future contingency receives considerable support from modern physics, in particular, quantum mechanics. ${ }^{14}$ According to the most widely accepted interpretations of the theory among physicists, events at the quantum level are genuinely indeterministic. ${ }^{15}$ If that's right, then there are future contingents. Again, this is not a proof. There are several competing and empirically equivalent interpretations of quantum mechanics, some of which are deterministic. But these deterministic interpretations involve the additional postulation of non-local 'hidden variables' and are for that reason somewhat less parsimonious. That doesn't entail they are wrong, but again, ceteris paribus, it does leave the indeterminists in the stronger dialectical position.

Third, as Robert Kane has recently pointed out, we have deep-rooted intuitions about moral responsibility that are strongly tied to the sense that we are ultimately responsible for at least some of our choices. By 'ultimate responsibility' Kane means that if we trace the causal ancestry of our choices back far enough, we would eventually arrive at an indeterministic 'self-forming action' over which we ourselves had unconditional power to do otherwise. ${ }^{16}$ To develop this thought a bit, consider that the choices we make over time shape and mold our character. Over time, our character may become so settled, so habit-bound in certain respects that we cannot do otherwise. A long-time addict, for example, may find it literally impossible to quit under his own power. But if we hold the addict morally responsible for his

\footnotetext{
${ }^{13}$ For a presentation of this charge see Ware (2000), ch. 4 .

${ }^{14}$ For a philosophical overview of quantum mechanics, see Sklar (1992), 202ff.

${ }^{15}$ See, for example, Shimony (1988).

${ }^{16}$ Kane (2006), ch. 11.

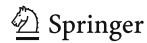


addiction, that is because we think that at some earlier point in his life he had it within his power to do otherwise and that, had he done so, he could have avoided or at least mitigated his current mess. In short, even if moral responsibility is compatible with some of our choices being determined, a thoroughgoing determinism seems to be incompatible with moral responsibility. Given that we have good reason to think that there is such a thing as moral responsibility, we therefore have good reason to think that all-embracing determinism is false, and thus that there are future contingents.

Fourth and finally, theological determinists have a significantly harder time with the problem of evil, than do free-will theists. According to theological determinism, God knowingly and willingly ordains "whatsoever comes to pass"17 and is the sole ultimate sufficient cause of all that happens. That means that every evil thing, from the Fall to the Holocaust to the eternal damnation of the reprobate, is something that God either directly brings about or irresistibly sets in motion. Frankly, for a theist to take this view is like giving atheists a slow pitch right down the middle of the plate. It's quite hard to resist the impression that God's ordaining and bringing about such evils is incompatible with his being maximally good. Free-will theists can offer the free-will defense and the soul-making theodicy to partially defuse the objection many evils are the result of creaturely indeterministic freedom, itself a very good thing to have, and so God could not have prevented those evils without foregoing a counterbalancing good. Open theists can defuse things a bit further by denying that God could have infallibly known in advance that such evils were going to happen; hence, God could not have ordained those evils. In contrast, theological determinists have comparatively little to say in response to the problem of evil other than to jump immediately into the notorious 'skeptical theist' rejoinder - who are you, $\mathrm{O}$ man, to judge the Almighty? ${ }^{18}$ Frequently this type of response misses the point. The issue isn't one of judging God, but rather of judging a particular theory of God, or of divine providence. But even when developed in a serious and relevant way, ${ }^{19}$ overreliance on the skeptical theist strategy has the significant drawback of undermining the confidence we place in our moral intuitions. ${ }^{20}$

In summary, the positive case for future contingency seems fairly strong. At the very least, it is enough to place the burden of proof on the nay-sayers. In addition, for a theist to deny future contingency makes the otherwise difficult problem of evil well-nigh intractable. On the whole, then, theists are much better off if they affirm future contingency.

\footnotetext{
${ }^{17}$ Westminster Confession of Faith 3.1. The classic defense of theological determinism is Jonathan Edwards' 1754 work Freedom of the Will.

${ }^{18}$ Cf. Romans 9:20.

${ }^{19}$ For example, Wykstra (1984).

${ }^{20}$ The sophisticated skeptical theist proposes that we may not be in a good epistemic position to distinguish between genuinely gratuitous evils and ones that are only apparently so, where a 'gratuitous evil' is one that is neither necessary to bring about a greater good nor necessary to avert a greater evil. The worry is that reliance on skeptical theism as a carte blanche response to the evidential problem of evil requires shifting from the moderate and plausible "we are often not in a good epistemic position to identify gratuitous evils" to the extreme and implausible "we are almost never in a good epistemic position, etc." That this seriously undermines our moral confidence is forcefully argued by Hasker (2004), ch. 3.
} 


\section{On Behalf of AC Incompatibility}

I'm now going to argue that AC incompatibility, or (5), follows from plausible semantic assumptions, in particular, the principle of charity. To set the stage, let's consider a future contingent event. Suppose that a fair coin has just been flipped and that right now at time $\mathrm{F}$ (the time of flipping) the world is perfectly indeterministic (50-50) with respect to whether the coin lands heads or tails. Suppose further that moments later at time L (the time of landing) the coin lands heads. The question we want to answer is whether it was true at or before $\mathrm{F}$ that the coin was going to land heads at L. How we ought to answer this question depends on which of two semantic theories regarding the significance of the unqualified predictive use of 'will' is correct. Following Arthur Prior, I will call these the 'Ockhamist' and 'Peircean' theories, respectively. ${ }^{21}$

According to Ockhamism, the truth value of a proposition about the future depends solely on what is the case at the future time (implicitly) referred to in the proposition. Thus, the truth of "The coin will land heads at L" depends solely on what is the case at L. If, when L arrives, the coin has landed heads, then the proposition has always been true. Since we are supposing that the coin did land heads at L, it therefore has always been true that the coin was going to land heads at L. At all times prior to $\mathrm{L}$, the future was alethically settled in that respect. Generalizing, it follows from Ockhamism that any proposition about a future contingent has either always been true or has always been false. The future has always been alethically settled in all respects.

In contrast, the Peircean proposes that whether a proposition about the future is true at a given time depends on whether sufficient conditions for its truth obtain at that time. Thus, "The coin will land heads at L" is true at F, says the Peircean, only if sufficient conditions obtain at $F$ for the coin's landing heads at L. Likewise, "The coin will not land heads at L" is true at F just in case sufficient conditions obtain at F for the coin's not landing heads at L. In general, then, no 'will' or 'will not' propositions about future contingents are true because sufficient conditions for their obtaining are not yet in place.

Clearly the status of AC incompatibility hinges on the Ockhamist/Peircean debate. If the Ockhamists are right, then the future can be both causally open and alethically settled in the same respects at the same time, whereas if the Peirceans are right then the future cannot be alethically settled in any respect in which it is causally open. To settle this debate, and with it the truth or falsity of (5), we have to determine whether the strict, literal, and unqualified predictive usage of the future tense ('will' and 'shall') implies that sufficient conditions must be in place for the predicted event's eventual obtaining. I say 'strict', 'literal', and 'unqualified' here because it must be kept in mind that we are not interested in giving a merely descriptive semantics of ordinary language usage. Our goals are philosophical and rigorous in nature. We want to know whether it can be true in advance, without hedging of any sort, that some future contingent event will happen, without hedging of any sort. Ordinary language usage is too loose and imprecise to be decisive in

\footnotetext{
${ }^{21}$ Prior develops the 'Ockhamist'/'Peircean' distinction in Prior (2003), 39-58.

Springer
} 
these kinds of semantic debates. It is, however, the best place to start, and will help us to clarify the issue.

A cursory survey quickly reveals that ordinary language uses of 'will' in predictive contexts can carry different kinds and degrees of semantic force. Most obviously, predictions carry anticipatory force. They orient us forward in time, toward the 'not yet'. In addition, though not so obviously, predictions can carry illocutionary force. For example, when the admiral says "There will be a sea battle tomorrow" this may be tantamount to giving an order that brings about the predicted event. Furthermore, and more importantly for our purposes, predictions may carry a greater or lesser degree of modal or causal force (hereafter just 'causal force'), reflecting the idea that the world is now tending more or less strongly in certain directions. For example, if an astronomer predicts, "There will be a solar eclipse in Timbuktu on Tuesday" we may plausibly suppose that by 'will' he means 'will definitely'. That is, he may mean to imply that sufficient conditions for the eclipse's obtaining on Tuesday are now in place, such that it is inevitable or 'nowunpreventable'. Contrast that with a concerned mother's warning her child, "Don't go outside without your jacket on or you will catch a cold." In this case it seems clear that the mother does not mean 'will definitely' but rather something more like 'will probably'. Her prediction thereby carries a lesser degree of causal force than the astronomer's.

With those observations in place, let's return to our debate and note that, for Ockhamism, the anticipatory force of 'will' exhausts the philosophically relevant meaning of the word in predictive contexts. To predict that an event 'will' happen, says the Ockhamist, is just to say that it 'does' happen in the future, nothing more. Consequently, Ockhamists will resist any suggestion that predictions need carry any more causal force that of the bare possibility of the event's occurring. Thus, to accommodate predictions that do carry significant causal force, Ockhamists have to append strengthening qualifiers, as in 'will definitely'. In contrast, Peirceans believe that strict and unqualified predictive uses of 'will' imply that the event is nowunpreventable and therefore carry maximal causal force. Thus, to accommodate predictions that carry less causal force, Peirceans have to append weakening qualifiers, as in 'will probably'.

Now consider the following list of qualified predictions arranged in increasing order of causal force:

\section{"It will possibly rain tomorrow." (probability $>0$ ) \\ "It will probably rain tomorrow." (probability $>0.5$ ) \\ "It will definitely rain tomorrow." (probability $=1$ )}

Where should the unqualified "It will rain tomorrow" be situated with respect to that sequence? Initially, it appears to be somewhat weaker than "It will definitely rain tomorrow," but also clearly stronger than "It will probably rain tomorrow." The latter is the case because "It will rain tomorrow" represents the future as settled and determinate in that respect, whereas adding the 'probably' qualifier leaves matters open or indeterminate. But if "It will rain tomorrow" is stronger than "It will probably rain tomorrow" then it is not clear how we can avoid equating it with "It will definitely rain tomorrow." The sense that the latter is too strong reflects, I 
suggest, our tendency to lose sight of the fact that what we're interested in is a semantics for 'will' in its strict, literal, unqualified, predictive usage, and not a merely descriptive semantics of its ordinary language usage. If this is right, then comparisons of 'will' with 'will probably' and 'will definitely' supports Peircean semantics over against Ockhamism by suggesting that strict, unqualified predictive uses of 'will' carry maximal causal force.

In response, Ockhamists may suggest that we should construe the qualifier 'probably' in 'will probably' as merely epistemic. Thus, Freddoso asks us to imagine an indeterministic coin-flipping scenario in which a person with accurate knowledge of the odds says before the coin lands, "It will land heads." Her claim, he insists, is not that the coin 'will probably' land heads but that it unqualifiedly 'will' land heads. If she were, under challenge, to hedge her prediction with 'probably', Freddoso says that this would merely reflect her waving confidence, and would not be a retraction of the original claim that the coin 'will' land heads. In addition, Freddoso points out that if the coin does land heads it would be natural for us to say to her "Gee, you were right," implying that her claim was true when she made it simply because things turned out that way. From this, he concludes that Ockhamist semantics is correct. $^{22}$

There are two issues raised by Freddoso. The first is his claim that qualifications applied to predictive uses of 'will' can be viewed as merely epistemic. The second is his claim that only Ockhamism can adequately account for our common practice of retrospectively attributing 'truth' to contingently successful predictions. I will address these in reverse order.

Freddoso is certainly correct that we do use words like 'true', 'right', and 'correct' is a retrospective or valedictory sense. But little follows from this given the wellknown fact of linguistic-semantic underdetermination, the point that, in general, there is a many-to-many correlation between sentence type and token meaning. Different sentence types can have the same meaning (e.g., "Snow is white" and "Der Schnee ist weiss") and different tokens of the same sentence type can differ in meaning (e.g., "It is raining" uttered at two different spatio-temporal locations). As a result, interpretation is a fallible process, often difficult, and frequently inconclusive. The moral is that we cannot simply read a semantics off of observations of how people talk. In particular, it does not follow from the fact that English-speakers sometimes retrospectively apply words like 'true' to sentences like "X will obtain" (after it has become clear that X has obtained) that the proposition expressed by that sentence was antecedently true.

Furthermore, the Peircean can easily account for this kind of linguistic behavior. Recall that the strict, Peircean truth conditions of "X will obtain at $t^{*}$ " uttered at time $t$ include both X's obtaining at $t^{*}$ and sufficient conditions for X's obtaining at $t^{*}$ obtaining at $t$. Outside of specialized contexts like philosophy, such strictness of use is not to be expected. So it would be improper to assume that the same truth conditions must apply without qualification to ordinary language locutions. Hence, the Peircean can say, when we retrospectively use the word 'true' of sentences like "The coin will land heads" after it has become clear that the coin did land heads, we

\footnotetext{
${ }^{22}$ Fredosso (1988), 71-72.

钐 Springer
} 
are speaking loosely but not inappropriately because we recognize correctly that part of its truth conditions have been fulfilled, namely, the coin's landing heads.

Let us now turn to Freddoso's first claim, namely, that qualifications applied to predictive uses of 'will' can be viewed as merely epistemic. There is a serious problem with this proposal. By separating the semantic content of a claim from the epistemic state of the person making the claim it runs directly counter to a highly plausible interpretive principle, namely, the principle of charity. The principle says that a person S's utterances ought to be interpreted, provided it is textually and contextually plausible to do so, in such a way that we take them to reflect a coherent set of beliefs that is reasonable in light of the experiences and evidence available to $\mathrm{S}$. In other words, before concluding that $\mathrm{S}$ is saying something stupid or talking nonsense, we should give $S$ the benefit of the doubt and try to interpret $S$ 's utterances in such a way that whatever claims we impute to $\mathrm{S}$ seem like they would be assertible for her. Thus, if $\mathrm{S}$ seems to make a claim that is not assertible for $\mathrm{S}$ in a context, then we should either (i) impute to $\mathrm{S}$ a different claim, one that does seem assertible for her in the context, (ii) impute to $\mathrm{S}$ additional beliefs so that the claim does become assertible for her, or (iii) construe S's utterance as something other than a claim. In general, the principle of charity tells us to interpret S's utterances in such a way as to keep their putative semantic content and S's putative epistemic states in sync, so that the former does not range beyond the latter.

Let's apply this to Freddoso's example. When S says "The coin will land heads" we have to ask ourselves what $\mathrm{S}$ could plausibly mean. There are several possibilities. For one, S's utterance might reflect a belief on her part that the world is strongly tending in the direction of the coin's landing heads. (Perhaps S thinks the coin is biased, or perhaps she has committed the gambler's fallacy and thinks that the coin is 'due' to land heads.) In that case, S's utterance expresses a genuine prediction, one we may cash out in either 'will definitely' or 'will probably' terms depending upon how strongly we think $\mathrm{S}$ believes the world to be tending in that direction. In Freddoso's case, however, $\mathrm{S}$ is explicitly said to be 50-50 on how the coin lands. This raises some questions. Why does S say 'heads' rather than 'tails'? Indeed, when asked which way the coin will land why doesn't S say 'I don't know'? The point is that $\mathrm{S}$ seems to be in no epistemic position to claim that the coin will land heads. Hence, that claim is not assertible for her in this context. ${ }^{23}$ Accordingly, the principle of charity encourages us to consider other possibilities. Perhaps S's utterance is elliptical for a different claim, such as the autobiographical "I hope that the coin lands heads." Or perhaps S's utterance is not a claim at all but an illocutionary speech act like "I guess heads" or "I hereby select heads." In any case, the Ockhamist is caught in a dilemma. When S says "The coin will land heads" either $\mathrm{S}$ is really claiming that the coin will land heads or $\mathrm{S}$ is not. If $\mathrm{S}$ is making that claim, then it reflects a belief on S's part that the world is really tending in that direction, in which case the utterance is not an instance of the non-causal usage of

\footnotetext{
${ }^{23}$ If it's not clear that the claim is not assertible for $\mathrm{S}$ because $50-50$ seems close enough, then change the example to, say, roulette, in which the odds of the ball's landing on a particular number are 1 in 38 . Were a person to say in this context "The ball will land on 20 " we would naturally be hesitant to construe that as reflecting a genuine belief on her part since we know, and presume that she also knows, that it is much more likely that the ball not land on 20. But if she doesn't really believe what she's saying, then it's not a genuine prediction. It's predictive in form, but not in content.
} 
'will' that Ockhamists want. If, however, S is not making that claim, then we no longer have a clearly predictive usage of 'will'. Either way, the principle of charity seems to rule out the possibility of there being genuine predictions (utterances that make predictive claims, not just ones that are superficially predictive in form) that have no causal force. If that's right, then Ockhamist semantics has nothing to apply to.

This problem, that predictions as understood in strict Ockhamist fashion are not even in principle assertible and thus not genuine predictions, is one that Arthur Prior has brought into particularly sharp focus:

I think I can attach intelligible senses to the phrases 'was true yesterday' and 'was the case yesterday' which give the Occamist results; but I cannot find any such sense for 'was known yesterday'. I can by my free choice, not exercised until tomorrow, cause a person's guess, made yesterday, to have been a correct one (I do this simply by deciding to do what he guessed I would)....But while contingent futures, and contingent future-infected pasts, can in this way be correctly or incorrectly guessed, I cannot see in what way the alleged knowledge, even if it were God's, could be more than correct guessing. For there would be ex hypothesi nothing that could make it knowledge, no present ground for the guess's correctness which a specially penetrating person might perceive. $^{24}$

Prior's complaint is based on the fact that, according to Ockhamism, to assert that "X will obtain at $t^{*}$ " is to claim nothing more than that at some time $t^{*}$ subsequent to the moment of utterance, $\mathrm{X}$ obtains. In other words, the truth of the claim depends solely on whether $\mathrm{X}$ is the case when $t^{*}$ arrives, which means that its truth conditions are completely independent of any present grounds "which a specially penetrating person might perceive." As a result, no present grounds could help one come to know or justifiably believe that "X will obtain at $t^{*}$." How then, wonders Prior, could anyone, even God, be in an epistemic position to make such a claim? ${ }^{25}$ Indeed, given Ockhamist semantics, how could any unqualified future-tense utterance express anything more than a mere guess?

To avoid this consequence we have to tie the truth conditions of " $\mathrm{X}$ will obtain at $t^{*}$ " not just to what is the case at $t^{*}$ but also to what was previously the case at some earlier moment, $t$. This is exactly what Peirceans do. More precisely, they hold that "X will obtain at $t^{*}$ " is true at $t$ only if sufficient conditions obtain at $t$ for $\mathrm{X}$ 's eventual obtaining at $t^{*}$. Accordingly, Peirceans have no problem accounting for the assertibility of true propositions about the future. Given that sufficient grounds for the truth of "X will obtain at $t^{*}$ " obtain at $t$ and are accessible to $\mathrm{S}, \mathrm{S}$ is in a position to assert that $\mathrm{X}$ will obtain at $t^{*}$.

Summing up, I have argued that the truth or falsity of (5), or AC incompatibility, stands or falls on the Ockhamist/Peircean debate on the semantics for predictions. And I have argued by appealing to the principle of charity that the Ockhamist semantics cannot account for the assertibility of propositions about the future,

\footnotetext{
${ }^{24}$ Prior (2003), 49.

${ }^{25}$ Compare Ockham's frank admission that "It is impossible to express clearly the way in which God knows future contingents" (Ockham 1983, p. 50). 
whereas the Peircean semantics can. Since the principle of charity is a highly plausible interpretive principle, one that we would be hard pressed to do without, and since we think we do know some propositions about the future and take ourselves to be warranted in asserting them, Ockhamism is unacceptable. Hence, the Peircean semantics is correct, and (5) is true.

\section{Conclusion}

As noted in section one, open theism is the conjunction of (1) theism (understood in a broadly classical sense), (2) future contingency, and (3) EC incompatibility, which together entail (4) the epistemic openness of the future for God. In section two I argued on behalf of (2). In section three I argued on behalf of (5) AC incompatibility, which entails (3) given the truism that what is not true cannot be known. It follows that open theism is correct if (1) is correct. It also follows that open theism's main competitors among broadly classical forms of theism, namely, theological determinism and the various forms of non-open free-will theism (e.g., Molinism and Ockhamism) are both untenable.

\section{References}

Basinger, D. (1996). The case for freewill theism: A philosophical assessment. Downers Grove, IL: InterVarsity Press.

Cobb, J. B., \& Pinnock, C. H. (Eds.) (2000). Searching for an adequate God: A dialogue between process and free will theists. Grand Rapids, MI: Eerdmans.

Fischer, J. M. (Ed.) (1989). God, foreknowledge and freedom. Stanford, CA: Stanford Univ. Press.

Fredosso, A. J. (1988). Introduction. In Luis de Molina, On divine foreknowledge: Part IV of the Concordia, tr. A. J. Fredosso (pp. 1-81). Ithaca: Cornell Univ. Press.

Hasker, W. (1989). God, time, and knowledge. Ithaca, NY: Cornell Univ. Press.

Hasker, W. (2001). The foreknowledge conundrum. International Journal for the Philosophy of Religion, $50,97-114$.

Hasker, W. (2004). Providence, evil, and the openness of God. London: Routledge.

Kane, R. (2006). A contemporary introduction to free will. Oxford, Oxford: Univ. Press.

Ockham, W. (1983). Predestination, God's foreknowledge, and future contingents, 2nd ed. Tr. M. M. Adams \& N. Kretzmann. Indianapolis: Hackett.

Prior, A. N. (2003). The formalities of omniscience. In Per Hasle et al. (Eds.), Papers on time and tense (pp. 39-58). Oxford: Oxford University Press.

Rhoda, A. R. (2008). Generic open theism and some varieties thereof. Religious Studies (in press).

Shimony, A. (1988). The reality of the quantum world. Scientific American, 258, 46-53.

Sklar, L. (1992). Philosophy of physics. Boulder, CO: Westview Press.

Ware, B. A. (2000). God's lesser glory: The diminished God of open theism. Wheaton, IL: Crossway.

Wykstra, S. J. (1984). The Humean obstacle to evidential arguments from evil: On avoiding the evils of 'appearance'. International Journal for Philosophy of Religion, 16, 73-93.

Zagzebski, L. (1991). The dilemma of freedom and foreknowledge. Oxford: Oxford Univ. Press. 